\title{
Information - Internet - Power: how the Information transforms into Power through the Internet
}

\author{
A.V. Vashenko ${ }^{1, \mathrm{a}}$, S.A. Odintsov ${ }^{1, \mathrm{~b}}$ \\ ${ }^{1}$ Kuban State University, 350040 Stavropolskaya str. 149, Krasnodar, Russia
}

\begin{abstract}
The Internet is a technology that has significantly changed the modern world. Originated as military technology, in the course of time, it, step by step, has penetrated into all spheres of society and influenced all of them. The Internet has become mostly wide-spread in political and business spheres. Politicians and PR-managers have found appropriate ways how to use this technology in their own interests. The Internet has become a platform for advertising and promotion of one's ideas. At first, the Internet gained popularity exclusively in high-income countries, as computers and the Internet availability was quite costly. But with time, costs plummeted and computers and the Internet became gradually available in lowincome countries, where it has become popular very fast, but the ways of its use vary considerably. In this article the authors research features of using modern technologies in the West and the East, analyse interaction between the globalization processes and development of the internet technologies, and describe the South or the East states reaction to pressure from the North or the West countries, which using the Internet as a platform for promoting their own interests.
\end{abstract}

\section{Introduction}

Modern technologies have completely changed the world. The Internet, that initially was named ARPANET was being conceived as a military technology, the main idea of which was to provide reliable transmission of information in case of Nuclear War. But as soon as this technology came out of a closed military quarters it became quickly widespread in different spheres. How can we explain such popularity and rapid spread of the Internet? To answer this question we must consider two things - scientific and technical progress (hereinafter STP) and globalization. STP has an impact not only on technology but on the society itself since the Internet emerged as a result of STP and it has become an integral part of the social, economic, international, political and financial spheres of society. The process of globalization strengthens the role of the Internet in social life, because legal network actors, such as the Transnational Corporations (hereinafter TNC) and Transnational Banks (hereinafter TNB), use the Internet to increase their influence. That is why we are faced with the following problem - the pressure of the leading actors of globalization (TNC's and TNB's) causes an asymmetrical response of the 2nd and 3rd world countries. This confrontation can be described as follows: the 1st world countries possess a monopoly on high technology, weapons of mass destruction, resources

\footnotetext{
${ }^{a}$ Corresponding author: dean.hist@kubsu.ru

${ }^{\mathrm{b}}$ Corresponding author: odintsov@kubannet.ru
}

and, in principle, they are leaders in all aspects of structural power and use their influence to achieve their own interests, primarily financial. On the other side, the 2nd and 3rd world countries possess very limited access to all these elements and begin to use available methods (asymmetrical) to protect their interests, survive and preserve their own identity in modern globalizing world. How is this implemented in practice? Improper use of force, violation of sovereignty, interventionist policies of Western countries leads to an asymmetrical response in the form of uncontrolled migration from South to North. This problem causes another one - demographic. The high birth rate among immigrants, coupled with the low birth rate of indigenous population leads to changes in the ethnic and religious composition of the population of host countries to such an extent that it threats the European civilizational identity. And the third but no less important problem is terrorism as the most extreme reaction to the actions of Western countries. In fact this is an asymmetric intervention!

The main objective of this research is to analyse the process of transforming information into the "Force" through communication. To solve this task we should:

- $\quad$ Analyse the nature of STP;

- Analyse the process of globalization;

- Allocate the main actors of globalization;

- Study the basic processes of STP which are affecting the social system. 


\section{Review of related research}

The researchers conducted in the framework of this investigation are of different nature and can be divided into several groups. The first group includes the works devoted to the study of processes of globalization - these include the works of A.V. Buzgalin [1], N.A. Kosolapov [2], M.A. Khrustalev [3], A.D. Bogaturov [4], N. Chomsky[5], I. Wallerstain [6]. The second group are the works devoted directly to the Internet technologies and cyberspace and possible threats posed by them. This group consists of works by E. and X. Toffler [7], J. Der Derian [8], T.L. Tropina [9], J.A. Lewis [10]. The third group a study is related to the various aspects and problems of cyberspace and the Internet technologies, such as the ability to use them for military purposes, as well as in the information war, the penetration of the Internet technologies into political and social spheres of life. These include works by scholars such as M. But [11], K. Grey [12], O.N Kalinowski [13], V.I. Orlyanskaya [14], V.N. Konyshev [15].

\section{Analysis of the Internet technology influence on contemporary society}

Many analysts started to search the reasons of the USA defeat in the Vietnam War and study them after the conflict had finished. At this point the concept of structural realism, which has been put forward by Kenneth Waltz, appeared. Based on the structural concept of Power proposed by Waltz [16] the concept of Power can be divided into several components political, financial, military, technological and informational. With the time, the information factor increases and plays a very important role in political, military, economic and financial spheres of society; moreover, the development of the Internet technology increases the influence of information on all other spheres. It is also necessary to consider the concept of "foreign policy" - an activity of state actors beyond the national sovereignty, in the classic sense the action of one state on the international arena should cause an equivalent response of another state (the principle of "billiard balls"). Schematically it is represented in figure 1.

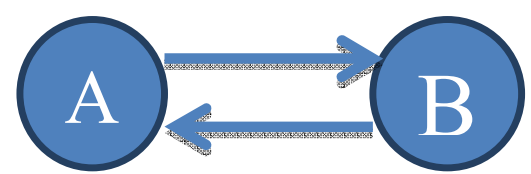

Fig. 1. "Billiard balls"

By the beginning of the XXI century the classical scheme of interaction between actors on the international arena has been changed - due to the influence of globalization sovereignty. The scheme eroded because there appear new actors - TNC and TNB - who have come to the fore. For them it is more profitable to have free movement of capital across state borders, migration of labour, as well as free dissemination of information, advertising in particularly, which is often provocative.
Therefore, the scheme of interaction has been changed radically and is represented in figure 2 .

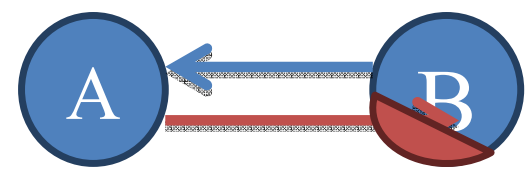

Fig. 2. Globalized world international relations

Besides TNC and TNB, new actors have appeared on the foreign-policy arena. They are represented by different Diasporas and Nonprofit Organizations (NPO), which are interested in broadening and deepening of globalization. Through their activity erasing of sovereignty of states occurs. For example, let us consider the impact of Diasporas on globalization. As it is known, Diasporas can be divided into global and regional, as well as into isolative, active and adaptive. In this context we are interested in the active Diasporas which change the environment to fit their needs and interests and these two global Diasporas are among the main supporters of globalization [17]. The consequences of such an influence on internal affairs of states can be various, including a change in one of the most important elements, which is necessary for the preservation of unity in the community. The historical memory is a link between the generations and the cultural heritage of society. However, the development of the Internet technologies not only contributes to strengthening and transference of information between generations, but to substitution of traditional social values and historical memories, which ultimately leads to the so-called "colour revolutions". The most striking examples of this is the crisis in Ukraine, contemporaries of which we are. Another example is a series of colour and flower revolutions, specific to the post-Soviet states in the second half of the 1990s and early 2000s.

But what are the conditions necessary for the implementation of such an impact on the population, because erasing the national identity and changing historical memory are not so easy? In this case the Internet is brought to the forefront - the main source of information for young generations. Through the information previously supplied via TV, and now over the Internet, the fragmentation of education and its forms of "mosaic thinking" occurs; certain behaviour patterns, which are most beneficial to Western countries as well as to other "engines" of globalization, are imposed. And such an imposing of behaviour models leads to an increased confrontation between the West (promoting these models) and the East, because these models are not acceptable for the East for a number of reasons such as different perception and another system of values.

One more factor which influences the popularity of behaviour models spread via the Internet is the myth of anonymity in the Internet. It is considered that information published in the Internet and governments of different states trying to hide it from society so that it seems a very strange and absurd idea in the Internet. This feature of the Internet can be used for changing the historical memory of population, when thoroughly planned and disseminated information is published in the 
Internet changing people's historical memories and their thoughts of their past. Of cause we cannot deny the fact that sometimes the certain information leaks into the Internet which various states try to keep secret, one of the striking examples of this is the activity of the "WikiLeaks" portal and information published by E. Snowden, but unfortunately there is a lot of misinformation and specially published information. One more area, in which modern technologies have a very strong impact, is education. It seems that the universal access to the world's libraries and electronic encyclopaedias should simplify the access to knowledge, but this simplification depreciates the value of education, because young people start to think like that: "Why do I need to study this? I can find any information about everything in a few seconds in the Internet."

When thinking about all these moments people start to ask themselves - how does the information transform from an abstract concept to power, and the Internet influences this process. To answer this question it is necessary to understand how the Internet changes a traditional information transfer process. The first one - is an increasing flow of information, which is available to ordinary citizen, as well as simplifying ways of how to get information. If earlier people have been obliged to spend a lot of time for searching rare books only in large libraries, but now it is possible to download a lot of them without leaving a house. The second one is the increased speed of content generation (information). Before the advent of the internet if people wanted to get the latest news they needed to buy daily newspaper or watch TVnews, and it took one a few hours till the information about the past event was published. Today it takes a few second for uploading the information on the Internet. But with this, the modern society is faced with the problem of the reliability of information.

Now we can turn to global level to track the influence of the Internet technologies on modern world. The speed of spreading of the information and problem of authentication allows rich and developed states of the West or North to use the Internet technologies in their own interests. For example, one democratic West Country "A" has "reliable" information that nondemocratic East Country " $X$ " is developing or possessing the Nuclear Weapons. This information is being instantly spread by all media including different web-sites, social networks, forums, blogs, etc. and this way a special public opinion is formed among the citizens of other Western states. Using the support of the population, state " $\mathrm{A}$ " creates a coalition with its allies and begins a military company against the state " $\mathrm{X}$ " under the pretext of "preventing the proliferation of nuclear weapons and establishment of democracy". As the result of this operation the non-democratic regime of state " $\mathrm{X}$ " has been overthrown, but nuclear weapons have not been found at all, and this operation had a farreaching effect. This example clearly shows that in the current conditions by using the Internet technologies developed countries can unite their allies on the basis of objective or false information and form a public opinion favourable for to them. More over the use of the Internet technologies allows controlling the information flow not all of cause, but always if it damages the image of Western states in some way or represents their interests on the part of TBC and TNB. In the network they always publish the information, the main role of which is to change current public opinion.

But how can poor eastern countries respond to these processes? Due to inability of the countries to pay for great information-control centres and attempt of West countries to impose their modern values as well as to expand their influence through the expansion of globalization, the poor countries give an asymmetrical response, which is expressed in emergence of large number of terrorist organizations that call people to protect their values and culture, which (in their opinion) can be destroyed by globalization, increases the rates of migration and the birth rate in the East countries. There are 5 basic elements of asymmetric response used by countries of the South to protect against the pressure from the countries of the North.

The first one is the developing weapon of mass destruction and their carriers. North Korea acquired nuclear weapon, and it is a strong argument, especially when it is combined with the existing carriers. Only the suspicion in possessing of nuclear weapon led to intervention in Iraq, but North Korea has nuclear weapon and still escapes invasion.

The second possible answer is terrorism. For the $3 \mathrm{rd}$ world countries terrorism remains one of the affordable answer to enforcement actions of the "golden billion". Terrorism is an asymmetric intervention [18]. The ratio of expended resources and the results can be much higher than in the classical intervention. For example, the cost of carrying out terrorist attacks on September 11,2001 , according to the FBI, was just 303,772 dollars [19]. "Direct and immediate damage caused by the attacks of September 11 amounted to about 50 bln. dollars. Approximately the same damage has been caused to the world air carries. And the loss of the US stock market during the year amounted to 2 trillion dollars" [20].

The third answer is the activity of illegal network actors. These are drug syndicates, organizations with setup political goals, such as "Hezbollah" and "Al Qaeda", organized international criminality. In fact they are illegal TNCs having a similar structure and organization. Moreover illegal network actors tend to integrate into the legal network using, for example, banks or investing money into legal business.

Drug traffic is the fourth asymmetrical response of the poor "South", and this is not because Afghan farmers are "arrant knaves" (the Afghans themselves almost do not use heroin), just because the economic benefits from the production of drug are much higher than income from other economic activities. Drug traffic to Europe and the US is a part of the war against the "North". Once, Osama bin Laden stated that "the spread of drugs among Americans and Europeans (i.e. the Crusaders) contributes to their destruction"[21].

The fifth answer is migration coupled with high birth rates. Greediness of business, the desire to maximize profits for a long time overshadowed this issue, covering it with the beautiful concepts of multiculturalism. The 
collapse of these concepts, cartoon scandal in Denmark, the French Government's decision to ban the hijab in educational institutions, the success of the ultra-rights in the elections in France and Austria, the Breivik scandal in Norway are the indicators of the beginning of the crisis of the system. Migration and demography are the processes that state the ability to reprogram. When the external attributes remain the same, but the quality content, cultural code of the country is changing.

\section{Results}

That is why the dichotomy East-West grows into something more, and we can observe the appearance of binary pairs characteristic for this confrontation: information - disinformation, communication - isolation, strength (structural) - weakness (asymmetrical response), the new values (LGBT, secularization, lack of sovereignty) which are characteristic for globalization traditional values (family, faith, state) leading to the process of regionalization and isolation.

Table 1. Binary pairs

\begin{tabular}{|c|c|}
\hline \multicolumn{2}{|c|}{ Binary pairs } \\
\hline NORTH & SOUTH \\
\hline Information & Disinformation \\
\hline Communication & Isolation \\
\hline $\begin{array}{c}\text { Power (structural) } \\
\checkmark\end{array}$ & $\begin{array}{ll}\text { Weakness } & \text { (asymmetrical } \\
\text { response) }\end{array}$ \\
\hline$\checkmark \quad$ Political & $\checkmark$ Terrorism \\
\hline$\checkmark \quad$ Economical & Networks \\
\hline Financial & Migration \\
\hline Technological & Demography \\
\hline$\checkmark \quad$ Informational & Drug traffic \\
\hline Government & Against government \\
\hline Modern values & Traditional values \\
\hline$\checkmark$ LGBT & $\checkmark \quad$ Family \\
\hline Secularization & Faith \\
\hline Lack of sovereignty & State \\
\hline$\checkmark \quad$ globalization & Regionalization \\
\hline
\end{tabular}

\section{Conclusion}

The peculiarity of the present situation consists in the fact that it is not soluble under the existing system of international relations. The "North" cannot give up the pressure on the "South" because it is interested in preserving the neo-colonial model based on access to sources of raw materials and cheap labour. Preservation of this system guarantees high standard of living and social stability in the countries of the "golden billion". At the same time the pressure of the "North" does not only affect the economic sphere. It is also a question of the spread of political models and religious and cultural values. The "North" strives to create a homogeneous system based on common principles and values, assuming that this system will be more stable. In many ways these values are treated by the "North" as universal but they are not acceptable for the "South". We are coming to a situation when the "South" protects itself against the "North's" values in the form of the asymmetric response. Then the "North" increases structural military pressure. This entails strengthening of the asymmetric response (terrorism, migration, demographics, drug traffic), which again makes the 'North' to carry out the whole range of military operations. This spiral movement leads to tightening of confrontation and conflict.

\section{References}

1. A.V. Buzgalin, Inter. Trends, 2, 31 (2003)

2. N.A. Kosolapov, The theory and political anlysis of international relations (NOFMO, Moscow, 2002)

3. M.A. Hrustaljov, An analysis of the international situation and political expertise (Publ. house "Aspekt-Press", Moscow, 2008)

4. A.D. Bogaturov, The conflicts of decentralization of world system (URSS, Moscow, 2008)

5. N. Chomsky, Because We Say So (City Lights Publishers, N.Y., 2015)

6. I. Vallerstajn, World-Systems Analysis: Theory and Methodology ("University book", Saint-Petersburg, 2001)

7. A. and H. Toffler, War and Anti-War (Grand Central Publishing, N.Y., 1993)

8. J. Der Derian, Virtuous War: Mapping The Military - Industrial-media-entertainment Network (Westview Press, Boulder, 2001)

9. T.L. Tropina, Internet and terrorism: old aims news tools (Vladivostok, 2003)

10. A. Lewis James, Assessing the Risks of Cyber Terrorism, Cyber War and Other Cyber Threats (Center for Strategic and International Studies, 2002)

11. M. Boot, War Made New: Technology, Warfare and the Course of History, 1500 to Today (Gotham Books, N.Y., 2006)

12. C. Gray, Parameters, Spring 2005, 14 (2005)

13. O.N. Kalinovskij, VOENNAJa MYSL", 4, 39 (2001)

14. V.I. Orljanskij, VOENNAJa MYSL", 1, 62 (2008)

15. V.N. Konyshev, The military strategy of USA after the end of the Cold War (Nauka, Saint-Petersburg, 2009)

16. K. Waltz, Theory of International Politics (McGraw Hill, N.Y., 1979)

17. N. Chomsky, Because We Say So (City Lights Publishers, N.Y., 2015)

18. A.V. Vashhenko, Terrorism as an asymmetrical intervention (Krasnodar, 2010)

19. P. Beckett, TWSJ, 15 May, (2002)

20. V.M. Kulagin, Modern international security (KNORUS, Moscow, 2012)

21. V. Plastun, NATO and drug traffic (2007) www.afghanistan.ru/doc/9952.html 